УДК 347.922:347.23:(341.645:341.231.14)

DOI https://doi.org/10.51989/NUL.2021.4.7

\title{
ЗАСТОСУВАННЯ ПРАКТИКИ ЄВРОПЕЙСЬКОГО СУДУ З ПРАВ ЛЮДИНИ ПРИ РОЗГЛЯДІ СУДАМИ СПРАВ ПРО ЗАХИСТ ПРАВА ВЛАСНОСТІ
}

\author{
Островська Людмила Анатолівна, \\ orcid.org/0000-0003-4946-4044 \\ кандидат юридичних наук, \\ доцент кафедри цивільного процесу \\ Національного університету «Одеська юридична академія» \\ Тріпульський Григорій Якович, \\ orcid.org/0000-0003-2251-497Х \\ кандидат юридичних наук, \\ доцент кафедри цивільного процесу \\ Національного університету «Одеська юридична академія»
}

у статі здійснено аналіз основних чинників-перешкод застосування практики Європейського суду з прав людини (далі - ЄСПЛ) в механізмі захисту права власності. Підкреслено, що усталене застосування практики ЄСПЛ у захисті права власності є запорукою створення привабливого авторитету українського ринку нерухомості, що зможе підвищити кількість іноземних інвестицій та, отже, призвести до підвищення економіки держави загалом. Розмежовано поняття охорони та захисту права власності, акцентовано увагу, що практика ЄСПЛ застосовується як в охороні права власності, так і в усіх формах захисту права власності, але безумовним сьогодні $\epsilon$ те, що судова форма захисту $\epsilon$ найефективнішою і такою, в якій можна здійснити контроль за дотриманням практики ЄСПЛ. Було здійснено аналіз застосування практики ЄСПЛ щодо захисту права власності судами та виокремлено основні аспекти, що є перепонами в ії застосуванні. Встановлено і проаналізовано, що першим аспектом, перешкоджаючим застосуванню практики ЄСПЛ, $\epsilon$ неправильне, неоднозначне розуміння, що є практикою ЄСПЛ, які рішення можна застосовувати як джерело права, зокрема тільки рішення проти України чи всі рішення за аналогічними видами спорів. Другий аспект - це декларативне використання практики ЄСПЛ без обгрунтування ії з існуючими обставинами справи або використання такої практики ЄСПЛ, що не стосується або стосується опосередковано суті спору. Декларативне та неактуальне застосування практики ЄСПЛ, як доведено, призводить до ії формального існування в судових рішеннях, що продовжують ухвалюватися за нормами права, тобто фактично в механізмі захисту права власності дотриматися гарантій Конвенції щодо захисту права власності стає не можливим. Проаналізовано, що в нормах цивільного процесуального законодавства існує пряма вказівка в мотивувальній частині щодо обґрунтування вибраного джерела права, тому в статі з урахуванням того, що практика ЄСПЛ $\epsilon$ джерелом права, пропонується застосовувати актуальну практику ЄСПЛ та обґрунтовувати ї̈ зв'язок з тими обставинами справи, що розглядаються.

Ключові слова: практика Європейського суду з прав людини, захист права власності, цивільний процес, судові рішення, мотивувальна частина судового рішення.

\section{Ostrovska Liudmyla, Tripulskyi Hryhorii. Application of the practice of the European Court of Human Rights during court consideration of cases of property rights protection}

The article analyzes the obstacle factors to the application of the case law of the European Court of Human Rights (ECHR) in the protection 's mechanism of property rights. It is emphasized that the established application of the case law of the ECHR in the protection of property rights is the key to creating an attractive reputation of the Ukrainian real estate market, which can increase foreign investment and, consequently, improve the economy as a whole. The concept of protection and defense of property rights is differentiated, emphasis is placed on the fact that the case law of the ECHR is applied both in the protection of property rights and in all forms of protection 
of property rights, but it is unconditional that which can monitor compliance with the practice of the ECHR. The application of the case law of the ECHR on the protection of property rights by the courts was analyzed, and the main aspects that are obstacles in its application were identified. It is established and analyzed that the first aspect hindering the application of the ECHR practice is the incorrect, ambiguous understanding of the ECHR practice, which decisions can be used as a source of law, in particular, only decisions against Ukraine or all decisions on similar disputes. The second aspect is the declarative use of the case law of the ECHR, without substantiating it with the existing circumstances of the case, or the use of such practice of the ECHR, which does not concern or indirectly concerns the essence of the dispute. Declarative and irrelevant application of the case law of the European Court of Human Rights has been proven to lead to its formal existence in court decisions that continue to be adopted in accordance with the law, in fact it becomes impossible to comply with the Convention's safeguards. It is analyzed that in the norms of civil procedural law there is a direct indication in the motivating part of the justification of the chosen source of law, so the article suggests that the case law of the ECHR is a source of law to apply current case law and justify its connection with the circumstances of the case are considered.

Key words: case law of the European Court of Human Rights, protection of property rights, civil proceedings, court decisions, motivating part of the court decision.

Натепер в Україні склалась неоднозначна ситуація щодо застосування практики Європейського суду з прав людини (далі - ЄСПЛ) як джерела права в усіх видах юрисдикції й безпосередньо під час розгляду справ про захист права власності. 3 одного боку, на законодавчому рівні питання вирішено однозначно, відповідно до ст. 17 Закону України «Про виконання рішень та застосування практики Європейського суду з прав людини» суди застосовують у розгляді справ Конвенцію та практику Суду як джерело права [1]. 3 іншого ж боку, в судовій практиці зустрічаються непоодинокі випадки декларативного або непослідовного застосування практики ЄСПЛ, а також, як підкреслювалось у наукових та практичних джерелах, (не) релевантне ії̈ застосування. Для судового захисту права власності застосування практики ЄСПЛ є суттєвою гарантією дотримання прав власника, гарантованих Конвенцією про захист прав людини та основоположних свобод (далі - Конвенція), що для складної нині ситуації «ринку нерухомості» в Україні як одного з найважливіших сегментів економіки та бізнесу $\epsilon$ вирішальним.

Проблеми застосування практики ЄСПЛ під час розгляду справ щодо права власності в наукових національних джерелах знаходяться на стику розгляду цивільного права, цивільного процесу та інших галузей права. Серед науковців, які займалися розвитком питань застосування практики ЄСПЛ у цивільному судочинстві та в спра- вах про захист права власності, слід відзначити Н.Є. Блажівську, В.Г. Буткевича, Н.Ю. Голубєву, О.В. Дзеру, Р.А. Майданика, О.Л. Копиленка та інших. Застосування практики ЄСПЛ як джерела права, особливо в справах про захист права власності, незважаючи на існування певного розвитку наукового ії осмислення, продовжує залишатися як неоднозначне та непередбачуване. У даній науковій роботі будуть розглянуті лише деякі аспекти застосування практики ЄСПЛ під час розгляду справ про захист права власності з точки зору існуючих перешкод для створення гарантій стабільного механізму захисту прав власника.

Передусім слід зазначити, що в статті досліджено перешкоди застосування практики ЄСПЛ під час судового захисту прав власника. Але зводити ії застосування тільки до вирішення судами спорів, тобто в судовій формі захисту прав власника, було 6 не вірним і таким, що звужує сферу її застосування. Судова форма захисту $є$ тільки однією з можливих, хоча, безумовно, найефективнішою з існуючих сьогодні в Україні. Застосування практики ЄСПЛ $€$ обов'язковим у судовому вирішенні вже порушеного права власності, хоча може застосовуватися й за альтернативних судових форм захисту, наприклад під час розгляду справ третейськими судами. Хотілось би також підкреслити, що в судовій формі захисту існує механізм забезпечення дотримання судом висновків щодо застосування Конвенції 
національними судами, що теж підвищує гарантії дотримання положень Конвенції. Але, як неодноразово було зазначено, створення умов за для нормальної реалізації права власності та запобігання його порушень $є$ більш сприятливим для суб'єкта права власності й для всього цивільного обігу, ніж застосування складного механізму судового захисту [2]. Тобто ідеальним вбачається дотримання суб'єктами положень Конвенції під час реалізації права власності без необхідності звертатися до судового захисту порушених прав, і можна допустити, що існування ЄСПЛ, його практики як гарантування дотримання положень Конвенції буде необхідно до того часу, поки не сформується усталена практика застосування Високими договірними сторонами єдинообразного застосування ії̈ положень. Але натепер, як свідчить судова практика та аналіз звернень до ЄСПЛ, уявлена ситуація $\epsilon$ бажаною моделлю, а впровадження й застосування практики ЄСПЛ під час розгляду справ національними судами знаходяться на перехідному етапі.

Перший аспект - перешкода усталеного застосування практики ЄСПЛ як джерела права судами полягає в неоднозначному розумінні, що $€$ практикою ЄСПЛ в її співвідношенні з діючим законодавством. Як зазначено в ст. 1 Закону України «Про виконання рішень та застосування практики Європейського суду з прав людини», під практикою Суду розуміється практика Європейського суду з прав людини та Європейської комісії з прав людини. Серед рішень ЄСПЛ слід розрізняти: а) остаточне рішення європейського суду з прав людини у справі проти України, яким визнано порушення Конвенції про захист прав людини і основоположних свобод; б) остаточне рішення Європейського суду з прав людини щодо справедливої сатисфакції у справі проти України; в) рішення Європейського суду з прав людини щодо дружнього врегулювання у справі проти України; г) рішення Європейського суду з прав людини про схвалення умов односторонньої декларації у справі проти України.

Стосовно рішень ЄСПЛ слід виокремити дві складнощі застосування: чи слід вважати джерелом права в Україні практику, сформовану виключно стосовно України як держави-відповідача, та чи може бути таким джерелом практика, сформована в рішеннях щодо інших держав. Таке непорозуміння $\epsilon$ перепоною усталеного ії застосування не тільки в судовій практиці під час захисту права власності, а й має велике значення для залучення іноземних інвестицій у цивільний обіг «ринку нерухомості», оскільки тлумачення, виражене в практиці ЄСПЛ, $\epsilon$ універсальним для всіх країн, що підписали Конвенцію [3], та гарантує передбачуваність ризиків розвитку правових відносин захисту прав власності. Як підкреслювалось у практиці ЄСПЛ, рішення суду використовуються не лише для вирішення справ, які розглядаються, а, також взагалі для висвітлення, захисту та розвитку правил, установлених Конвенцією, що сприяє дотриманню державами зобов'язань, які вони взяли на себе як Договірні Сторони (Ireland v. the United Kingdom, 18 January 1978, $\S 154$, Series A no. 25, тa Jeronovics v. Latvia [ВП], no. 44898/10, § 109, 5 July 2016) [4]. Тобто кожне рішення ЄСПЛ, незважаючи на різницю внутрішніх національних законодавств й на те, яка країна з точки зору заявника порушила положення Конвенції, $\epsilon$ трактуванням саме застосування положень Конвенції та наднаціональних зобов'язань, взятих на себе Високими договірними сторонами. Наприклад, ст. 1 Протоколу № 1 закріплює поняття права на майно та його захисту, що застосовується в контексті Конвенції, в якій закріплено, що: «кожна фізична або юридична особа має право мирно володіти своїм майном. Ніхто не може бути позбавлений своєї власності інакше як в інтересах суспільства і на умовах, передбачених законом і загальними принципами міжнародного права. Проте попередні положення жодним чином не обмежують право держави вводити в дію такі закони, які вона вважає за необхідне, щоб здійснювати контроль за користуванням майном відповідно до загальних інтересів або для забезпечення сплати податків чи інших зборів або штрафів» [3]. Тобто прямо в самій Конвенції закріплено право держави вводити власні закони, які стосуються регулювання відносин власності. Саме тому під час вирішення справ про захист права власності 
слід застосовувати внутрішнє національне законодавство, але з урахуванням та у відповідності з Конвенцією та актуальним їі тлумаченням практикою ЄСПЛ.

Слід дійти висновку, що застосуванню підлягають як рішення проти України, так й інші рішення, оскільки змістом діяльності $€ С П Л \in$ тлумачення дотримання положень Конвенції та виконання її постулатів, оскільки тлумачення її положень $€$ універсальними.

Другим аспектом $€$ декларативне, формальне використання практики ЄСПЛ у національному судочинстві. Такий висновок не $\epsilon$ новелою, на нього не раз була звернена увага, наприклад, доволі змістове таке твердження можна знайти у висновках міжнародної конференції Верховного Суду України з права власності, пов'язаних із правом власності, захистом права на мирне володіння майном у практиці Європейського суду з прав людини, а також окремих аспектів регулювання відносин власності та захисту права власності в українському законодавстві: «Рішення ЄСПЛ мають бути застосовані українськими судами обов'язково, але таке застосування повинно бути обґрунтованим: адекватним, виваженим, виправданим. Водночас залишається певною проблемою необґрунтоване, формальне, а не змістове застосування практики ЄСПЛ, яке полягає в тому, що рішення ЄСПЛ суд зазначає в рішенні, цитує окремі його пункти, але насправді вириває з контексту рішення деякі висновки ЄСПЛ та зводить їх до абсолюту. Ця проблема яскраво проявляється в застосуванні рішення ЄСПЛ у справі «Стретч проти Сполученого Королівства» (у спорах, що стосуються повернення майна (у тому числі земельних ділянок) у державну або комунальну власність) та рішення ЄСПЛ у справі «Ісмаїлов проти Російської Федерації» (у спорах, які стосуються конфіскації майна як адміністративного стягнення за порушення митних правил» [5].

Такий аспект застосування практики ЄСПЛ у національному судочинстві України деякі практики називають не релевантне та маніпулятивне ії застосування [6]. Як відомо, застосування практики ЄСПЛ будується на принципі схожості правових систем, правових інститутів мате- ріального та/або процесуального права, а також схожості правового регулювання в ситуаціях, коли необхідно застосування схожого рішення. Релевантне застосування практики ЄСПЛ повинно бути побудовано на трьох засадах: схожості фактів, скарг або юридичних висновків. Тобто можна дійти висновку, що в кожній судовій справі в ухваленні судового рішення повинна бути застосована така практика

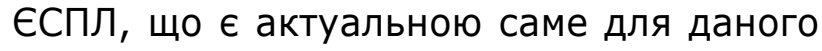
виду спору, а критеріями вибірки $є$ саме схожість фактів, самої скарги або тих висновків, яких дійшов у своїй практиці ЄСПЛ. Схожість фактів може бути трактована по-різному, але певні загальні критерії схожості викладених фактів дійсно існують. Фактичні обставини не повинні бути тотожними та не можуть бути такими, кожна справа, навіть за наявності одного й того ж предмету позову, не може мати тотожних підстав, обставин. Як акцентує керівник департаменту аналітичної та правової роботи апарату Верховного Суду Расім Бабанли: «3 метою належного застосування правової позиції ЄСПЛ потрібно обов'язково досліджувати факти, за яких ЄСПЛ ії̈ було сформульовано. Звісно, може йтися не про абсолютно тотожні «обставини-близнюки» або ідеальну схожість, однак відповідні обставини повинні мати принципову схожість та не мати принципових відмінностей і розбіжностей з фактами конкретної справи» [6]. Задля уникнення формального застосування практики ЄСПЛ, як вбачається, суди повинні обґрунтовувати в мотивувальній частині як посилання на норми діючого законодавства, так і на актуальні рішення ЄСПЛ, належним чином пов'язані 3 існуючими обставинами справи. Цивільний процесуальний кодекс України, зокрема п.п. 5-6, 4. 4 ст. 265, містить вимогу відносно обов'язку суду в мотивувальній частині судового рішення зазначати норми права, що застосував суд, мотиви їх застосування та норми права, на які посилалися сторони, котрі суд не застосував, мотиви їх незастосування [7]. 3 урахуванням положення законодавства про те, що суди застосовують практику ЄСПЛ як джерело права, слід дійти висновку, що обґрунтування висновків суду нормами права слід 
трактувати не тільки щодо застосування нормативно-правових актів, а й актуальною до існуючих обставин справи практикою ЄСПЛ.

3 урахуванням викладеного цікавим буде проаналізувати останнє рішення ЄСПЛ «Борисов проти України» (заява № 2371/11) від 4 березня 2021 року, що стосується саме Протоколу № 1, а саме щодо знесення нерухомого майна заявника на підставі судового рішення, яке набрало законної сили і згодом було скасоване як незаконне [8]. Суть справи полягає в тому, що гараж заявника було знесено на виконання рішення суду за позовом його сусідів про визнання недійсним договору купівлі-продажу гаражу, оскільки заявник здійснив незаконну реконструкцію, яка призвела до погіршення їхніх житлових умов (гараж був реконструйований у магазин). У даній справі цікавими уявляються доводи уряду стосовно невичерпності національних засобів юридичного захисту заявником і безпосереднє посилання на національну практику застосування, але відсутні посилання на застосування практики ЄСПЛ як із приводу вичерпності застосування національних механізмів захисту права власності, так і з розгляду суті спору, хоча така практика існує. Цікавим у висновку ЄСПЛ $є$ також акцент на те, що «хоча Верховний Суд України зупинив виконавче провадження про спірне знесення, його ухвала була постановлена із запізненням, оскільки на той момент нерухоме майно вже було знесене державними виконавцями. Ще пізніше скасу- вали рішення про знесення як незаконне та необґрунтоване. Ця запізніла реакція вищого судового органу помітно контрастує зі зразковою оперативністю державних виконавців у виконанні рішення про знесення, хоча вони мали усвідомлювати незворотний характер своїх дій і мали право зупинити виконання рішення на різних підставах, у тому числі тих, на які прямо послався заявник (див. пункти 10 та 25; для порівняння, рішення у справі «ВАТ «Нафтова компанія «Юкос» проти Pociï» (OAO Neftyanaya Kompaniya Yukos v. Russia), заява № 14902/04, пункт 654, від 20 вересня 2011 року). Ці обставини вказують на те, що, незважаючи на суворість заходу контролю, органи державної влади не діяли вчасно та в належний і послідовний спосіб (п.п. 47-48)» [8].

Підсумовуючи викладене, слід дійти певних висновків. По-перше, слід погодитися з думкою деяких учених щодо того, що впровадження нового за своєю суттю джерела права, яким $€$ практика ЄСПЛ, до національної правової системи, де традиційно єдиним джерелом права був нормативно-правовий акт, є довготривалим, інерційним процесом, що потребує особливої уваги, контролю з боку держави через різні інституції. По-друге, існуючі перешкоди її застосування свідчать про те, що суди все ж таки зробили перші кроки ії впровадження до національної судової практики, а увага науковців та практиків $є$ одним з інструментів додаткової стимуляції правильного застосування нового, не притаманного правовій системі, джерела права.

\section{ЛITEPATУPA:}

1. Про виконання рішень та застосування практики Європейського суду з прав людини : Закон України від 23 лютого 2006 року. Відомості Верховної Ради України. 2006. № 30. Ст. 260.

2. Тріпульський Г.Я. В Україні недооцінений ринок нерухомості, але $\epsilon$ великий потенціал. Юридична газета. 2021. URL: https://yur-gazeta.com/interview/v-ukrayini-nedoocineniy-rinokneruhomosti-ale-e-velikiy-potencial.html

3. Конвенція про захист прав людини та основоположних свобод : Закон України № 475/97-ВР від 17.07.1997 p. URL: http://zakon3.rada.gov.ua/laws/show/995_004

4. Посібник за статтею 1 Протоколу №. 1 Конвенції про захист прав людини та основоположних свобод. Захист власності. URL https://www.echr.com.ua/publication/zaxist-vlasnostiposibnik-zi-st-1-protokolu-1/

5. Висновки та рекомендації міжнародної конференції з права власності у висновках та рекомендаціях щодо питань, пов'язаних із правом власності, захистом права на мирне володіння майном у практиці Європейського суду з прав людини, а також окремих аспектів регулювання відносин власності та захисту права власності в українському 
законодавстві Верховного Суду України. Закон і бізнес. URL: https://zib.com.ua/ua/ print/120218u_verhovnomu_sudi_pidsumuvali_rekomendacii_schodo_zahistu_pr.html

6. Пушкар П., Бабанли Р. До питання про (не)релевантне застосування практики Європейського суду з прав людини: практичні поради. URL https://supreme.court.gov.ua/supreme/ pres-centr/zmi/700941/

7. Цивільний процесуальний кодекс України : Закон України від 18.03.2004 р. Відомості Верховної Ради України. 2004. № 40-42. Ст. 492.

8. Справа «Борисов проти України» (Заява № 2371/11). URL: https://zakon.rada.gov.ua/ laws/show/974_f57\#Text 